\title{
Groundwater and Human Development: Challenges and Opportunities in Livelihoods and Environment
}

\author{
Tushaar Shah \\ International Water Management Institute, Vallabh Vidyanagar, Gujarat, India
}

\begin{abstract}
At less than $1000 \mathrm{~km}^{3} /$ year, world's annual use of groundwater is $1.5 \%$ of renewable water resource but contributes a lion's share of water-induced human welfare. Global groundwater use however has increased manifold in the past 50 years; and human race has never had to manage groundwater use on such a large scale. Sustaining the massive welfare gains groundwater development has created without ruining the resource is a key water challenge facing the world today. In exploring this challenge, we have focused a good deal on conditions of resource occurrence but less so on resource use. I offer a typology of 5 groundwater demand systems as Groundwater Socio-ecologies (GwSE's), each embodying a unique pattern of interactions between socio-economic and ecological variables, and each facing a distinct groundwater governance challenge. During the past century, a growing corpus of experiential knowledge has accumulated in the industrialized world on managing groundwater in various uses and contexts. A daunting global groundwater issue today is to apply this knowledge intelligently to by far the more formidable challenge that has arisen in developing regions of Asia and Africa, where groundwater irrigation has evolved into a colossal anarchy supporting billions of livelihoods but threatening the resource itself.
\end{abstract}

\section{Global Groundwater Juggernaut}

Rapid growth in groundwater use is a central aspect of the world's water story, especially since 1950. Shallow wells and muscle-driven lifting devices have been in vogue in many parts of the world for the millennia. In British India (which included today's India, Pakistan and Bangladesh), wells accounted for over 30 percent of irrigated land even in 1903 (http://dsal.uchicago.edu/statistics/ 1894_excel) when only 14 percent of cropped area was irrigated. With the rise of the tubewell and pump technology, groundwater use soared to previously unthinkable levels after 1950. In Spain, groundwater use increased from $2 \mathrm{~km}^{3}$ / year to $6 \mathrm{~km}^{3}$ during 1960-2000 before it stabilized (Martinez Cortina and HernandezMora 2003). In the US, groundwater share in irrigation has increased, from 23 percent in 1950 to 42 percent in 2000 (http://water.usgs.gov/ pubs/circ/2004/ circ1268/). In the Indian sub-continent, groundwater use soared from around 10- 


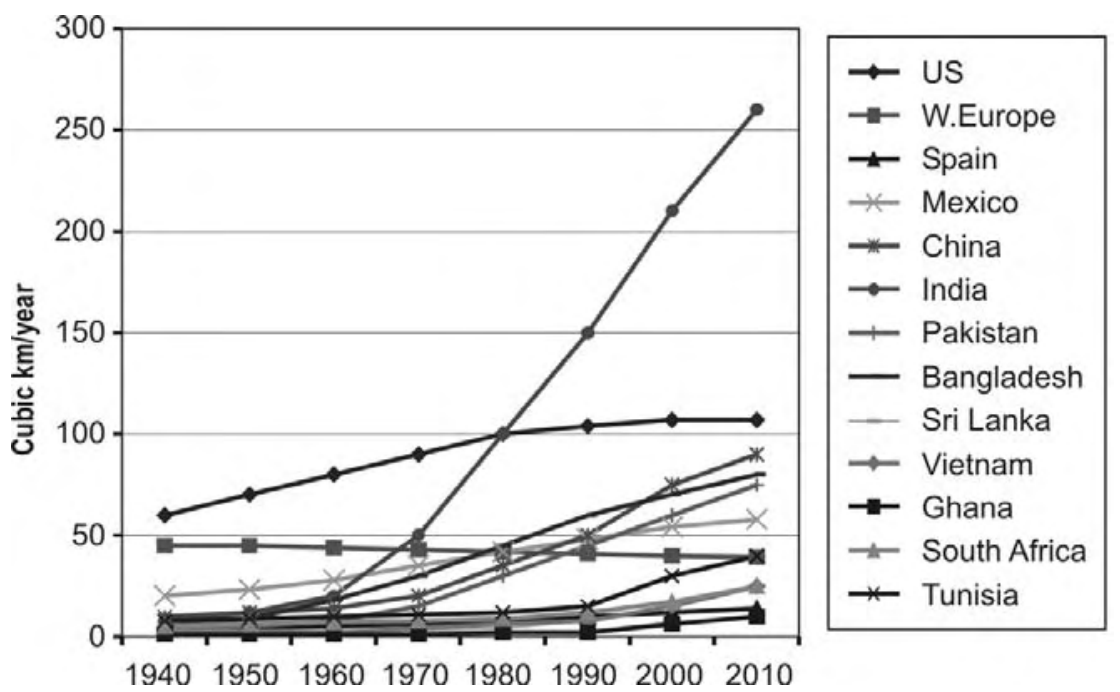

Figure 1. Growth in groundwater use in selected countries (author's estimates)

$20 \mathrm{~km}^{3}$ before 1950 to $240-260 \mathrm{~km}^{3}$ today (Shah et al. 2003a). Data on groundwater use are scarce; however, Figure 1 attempts to backcast the probable trajectories of growth in groundwater use in selected countries. While in the US, Spain, Mexico, and North-African countries like Morocco and Tunisia total groundwater use peaked during 1980's or thereabout, in South Asia and North China plains, the upward trend begun during the 1970s is still continuing. A third wave of growth in groundwater use is likely in the making in many regions of Africa and in some south and south-east Asian countries such as Vietnam and Sri Lanka (Molle et al. 2003).

\section{Typology of Groundwater Socio-ecologies}

At less than $1000 \mathrm{~km}^{3}$ /year, global groundwater use is a quarter of total global water withdrawals but just $1.5 \%$ of the world's annually renewable freshwater supplies, 8.2 percent of annually renewable groundwater, and 0.0001 percent of global groundwater reserves estimated to be between 7-23 million $\mathrm{km}^{3}$. Yet its contribution to human welfare is huge in five distinct types of groundwater socioecologies (GwSEs) based on intensive groundwater use, each embodying a unique pattern of interaction between socio-economic, demographic and ecological variables, and each presenting a distinctive groundwater management challenge:

\section{Type I: Habitat support GwSE's}

Groundwater has historically supplied water in numerous human settlements, urban and rural, around the world. According to one estimate, "..over half the world's population relies on groundwater as a drinking water supply." (Coughanowr,1994). Seventy percent of piped water supply in EU is drawn from groundwater. Management of Type I GwSEs presents unique challenges since, in the process of urbanization, the population of a habitat generally grows faster than 
its geographic span; as a result, pressure on groundwater resources underlying the habitat increases rapidly as villages grow into towns and thence into cities. The ubiquitous response combines import of surface or groundwater from a distant source, volumetric pricing, improved water supply infrastructure and service to crowd out private urban tubewells to reduce pressure on urban groundwater.

\section{Type II: Nonrenewable GwSE's}

Arid and semi-arid countries in the MENA (Middle East and North Africa) region-Saudi Arabia, Yemen, Jordan, Oman, Bahrain, UAE, Iran, Libya, Egyptdepend on either fossil or limitedly renewable groundwater. Some, such as Saudi Arabia, Jordan, Yemen and Libya experimented with intensive groundwater use in agriculture to secure food self-sufficiency; however, it is increasingly realized that the use of fossil groundwater-even in large reserves such as the Nubian aquiferneeds to be managed in a planned manner using different criteria than used for managing renewable groundwater. Virtual water imports, off-farm livelihoods, shifting and reduction in agricultural areas, wastewater treatment and reuse, desalination are elements of strategies used to ease pressure on fossil groundwater.

\section{Type III: Wealth-creating GwSE'S}

In recent decades, groundwater has become increasingly important in meeting water needs of industries and industrial agriculture in many developed countries such as Spain, US, and Australia. Three key characteristics of Type III GwSE's are: (a) users are normally few, large and identifiable; as a result, it becomes possible to create and enforce rules, norms, rights and economic incentives to regulate use by creating a formal economy; (b) using groundwater as a factor of production, Type III GwSE's generate substantial wealth which is shared by relatively small number of resource users; and (c) as a result, these attract and support scientific and technical wherewithal for intensive management of the resource and its use.

\section{Type IV: Livelihood supporting GwSE'}

In terms of groundwater quantity and numbers of people involved, by far the largest growth in groundwater use has occurred in sustaining subsistence crop and livestock farming which are the mainstay of billions of poor people in developing agrarian economies around the world such as India, Bangladesh, Nepal, and China. (see Figure 2) ${ }^{1}$. Out of the global annual groundwater use of $950-1000 \mathrm{~km}^{3}$, Type IV GwSE's likely accounts for half or more. From the resource governance viewpoint, these represent a different ballgame altogether because: (a) they are dominated by large diffuse masses of small users who are neither registered, nor licensed, operating as they do in totally informal irrigation economies untrammeled by laws and regulations; (b) unlike Type III GwSE's of Spain, US and Australia, Type IV GwSE's support large numbers of poor people but generate little wealth in absolute or relative terms ${ }^{2}$. A groundwater user in South Asia produces a gross output of

${ }^{1}$ The FAO estimates of groundwater irrigated area based on data provided by member governments are in my view gross underestimates for countries in South Asia. Even these under-estimates put into bold relief why sustainable groundwater use in agriculture has emerged as a key challenge in this region. 


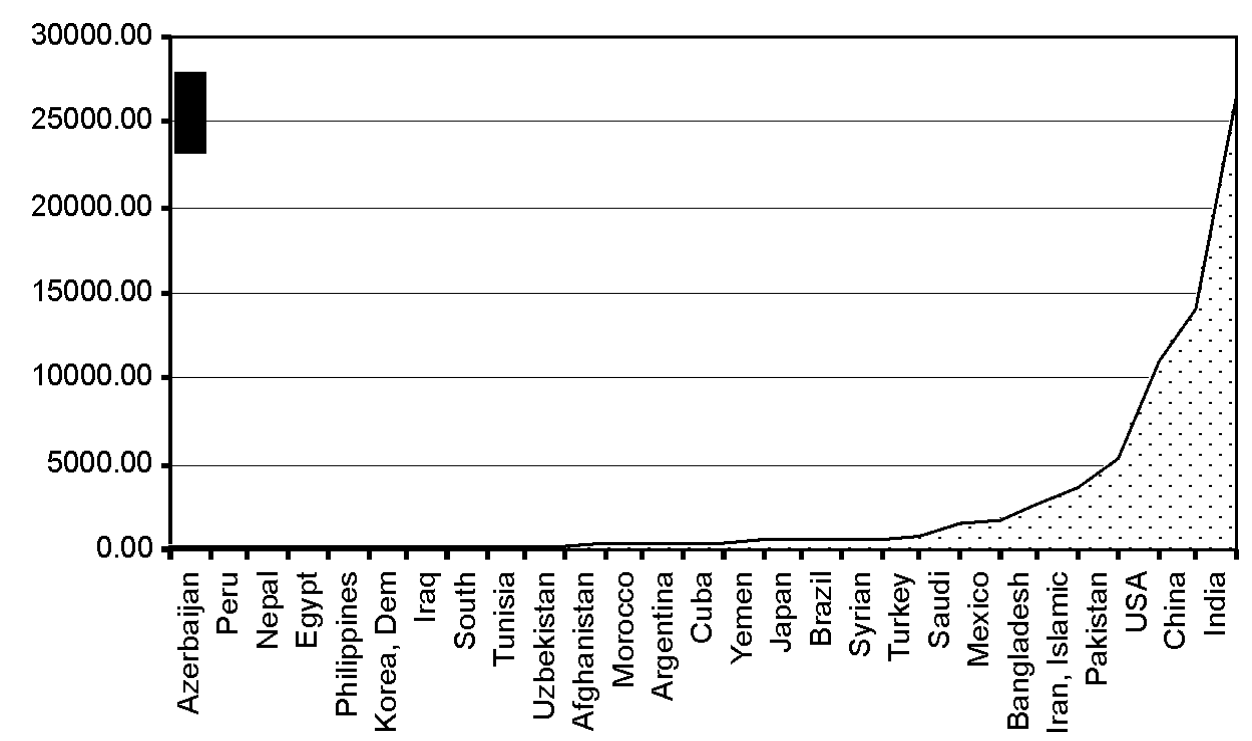

Figure 2. Groundwater irrigated area in countries with intensive groundwater use in agriculture (FAO Aquastat 2003 and other sources)

US \$ 400/ha from irrigating crops; in contrast, a Spanish farmer in Andalusia region generates gross output/ha of US \$ 8000/ha on average but can go up to US \$ 75000 (Llamas 2003); (c) despite these apparently low returns, small holders in Type IV GwSE's have huge stakes in groundwater irrigation because it has served as one of the largest and most potent 'poverty reduction' programs (DebRoy and Shah 2003) in recent decades; (d) since science, technology and management tend to get attracted to wealth generation more easily than to poverty reduction, Type IV GwSE's attract far less of groundwater management inputs than Type III GwSE's ${ }^{3}$.

\section{Type V: GwSE's based on trans-boundary aquifers}

Numerous aquifers in the world are shared by two or more sovereign states; most of these are small but some-like the Nubian with an estimated reserve of

\footnotetext{
2South Asia uses around $240-260 \mathrm{~km}^{3}$ of groundwater in agriculture annually providing supplemental irrigation to $60-75 \mathrm{~m}$ ha of grain, millet, pulse and fiber crops; however, the economic value of agricultural output this water supports is around US \$35-40 billion because it is used largely for low value subsistence grain crops by peasants. Spain, in contrast, uses $4-5 \mathrm{~km}^{3}$ of groundwater for irrigating 1 million ha of mostly grapes for wineries, and fruit and flowers for export to EU; and its economic value is estimated by Martinez Cortina and Harnandez-Mora (2003) at 4.5-10.7 billion Euros, or at 0.8 Euro to a US dollar, US \$ 5.6-13.4 billion!

${ }^{3}$ The resources available to groundwater organizations highlight the contrast. India uses $200 \mathrm{~km}^{3}$ of groundwater annually, which likely benefits 600 million rural people; but her Central Ground Water Board's annual budget is around US \$ 31 million (http://indiabudget.nic.in). The US uses $110 \mathrm{~km}^{3}$ in agriculture, which likely supports a million farmers. However, the USGS budget for 2005 is nearly US $\$ 1$ billion. Even allowing for Purchasing Power Parity, the differences in resources available to groundwater management agencies in the two types of groundwater socio-ecologies are evident (http:/ /www.usgs.Gov/budget/2005/ 05budgetpr.html).
} 
over 500,000 $\mathrm{km}^{3}$-are huge (Puri and El Naser 2003). As intensive groundwater use emerges in these aquifers, their effective governance becomes subject to a new class of problems needing unique institutional responses and mediating mechanisms. Management of shared aquifers between Israel and Palestine, between the US and Mexico, and amongst countries of the Nile basin who will share the Nubian illustrate these unique issues. For the purposes of this paper, however, we will ignore Type V GwSE's, important as they are in the global groundwater setting.

\section{Groundwater and Poverty in Asia}

Globally, growth in groundwater irrigation has had little to do with the occurrence of the resource; if anything, led essentially by demand-pull, intensive development has tended to occur in arid and semi-arid regions with relatively poor groundwater endowments. Regions with abundant rainfall and recharge-much of South America, Canada, South East Asia, and Southern China-make little use of groundwater in agriculture. Intensive groundwater use, where extraction $/ \mathrm{km}^{3}$ of annual recharge is high, has also had little to do with the geology of regions ${ }^{4}$. Instead, Type IV GwSE's have: (a) high population density; (b) high livelihood dependence on peasant farming dominated by small, fragmented land holdings; (c) arid to semi-arid and often monsoon climate. Of the 300 million ha of irrigated land in the world, some 85-95 million depend on groundwater ${ }^{5}$; over $85 \%$ of these areas are in India, Pakistan, Bangladesh, Iran and North China plains. All these have all the three characteristics outlined above. Bangladesh, with high precipitation, is more like South East Asian countries; but its flood-proneness makes groundwater irrigation critical for improved agricultural productivity it needs to support its very high population density. As a result, from only a few thousand shallow tubewells in 1980, Bangladesh has added nearly a million since then, raising its groundwater irrigated area from close to nothing in 1980 to 2.8 million hectare in 2000, which is $90 \%$ of its cultivated land (BBS 2002). Figure 3, which overlays tubewell density (each black dot represents 5000 groundwater structures) over population density in India and Pakistan Punjab, shows that high tubewell densities follow high population density in Indo-Gangetic basin where the resource is abundant to southern India where resource is very limited. However, tubewell density is low in Central India where population density is low but untapped resource is available. This is

\footnotetext{
${ }^{4}$ In India, intensive groundwater use occurs in the Ganga basin, which has excellent alluvial aquifers with abundant recharge; but it also occurs in southern peninsular India dominated by hard rock aquifers with low storage coefficients, as suggested by Figure 3 .

${ }^{5}$ These are author's estimates. FAO Aquastat (2003) estimates groundwater irrigated for Africa at 1.02 million ha, for Asia (excluding China) at 43.6 million ha, and North and Central America (excluding the USA) at 2.2 million ha (Burke, 2003). It also places total irrigated areas for member countries (excluding China and USA) at around $200 \mathrm{M}$ ha. FAO Aquastat data for most countries are 6-10 years old. Moreover, FAO places groundwater-irrigated area in India at just 26 million ha; however, the net area irrigated by groundwater in India in 2004 is more like 55-60 million ha at the least. The Minor Irrigation Census carried out by Government of India in 1993-94 placed net groundwater irrigated area at 30.13 $M$ ha 10 years ago (Gol 2001); and this census excluded Gujarat, Maharashtra, Karnataka and Tamilnadu, which represent huge Type IV GwSE's in India. All in all, I believe that in 2004, global irrigated area is more likely to be close to 300 than $200 \mathrm{M}$ ha; and groundwater irrigated area in Asia is more like $85-90 \mathrm{M}$ ha.
} 
perhaps why Africa with its low population density will never experience the kind of groundwater irrigation explosion that South Asia has.

Type IV GwSEs of South Asia and North China plains represent a veritable anarchy functioning on a colossal scale. India, for instance, has been adding 0.8-1 million new tubewells every year since 1990; and there is no sign of deceleration in this trend. One in four of India's farmers have invested in irrigation wells; most of the remaining buy pump irrigation service from their tubewell-owning neighbors. Government of India claims $60 \%$ of India's irrigated areas are served by groundwater wells; independent surveys suggest the figure may well be $75 \%$; and even more if conjunctive use areas are included. Much the same is true of Pakistan, Nepal terai, Bangladesh, and Hebei, Shandong, and Henan provinces in the Yellow river basin in North China plains. Governments and donors have invested heavily in building major dams and canal irrigation projects in these regions; but, as of now, by far the bulk of the irrigation-and livelihood benefits-are delivered by groundwater wells. Over half of the total populations of India, Pakistan and Bangladesh have a livelihood-stake in well irrigation. During 1970's, India discussed different strategies for irrigation command areas and for rain-fed farming regions. Thanks to groundwater development, there are hardly any rain-fed farming 'regions' or even villages in India; there are just rain-fed and mostly groundwater irrigated plots.

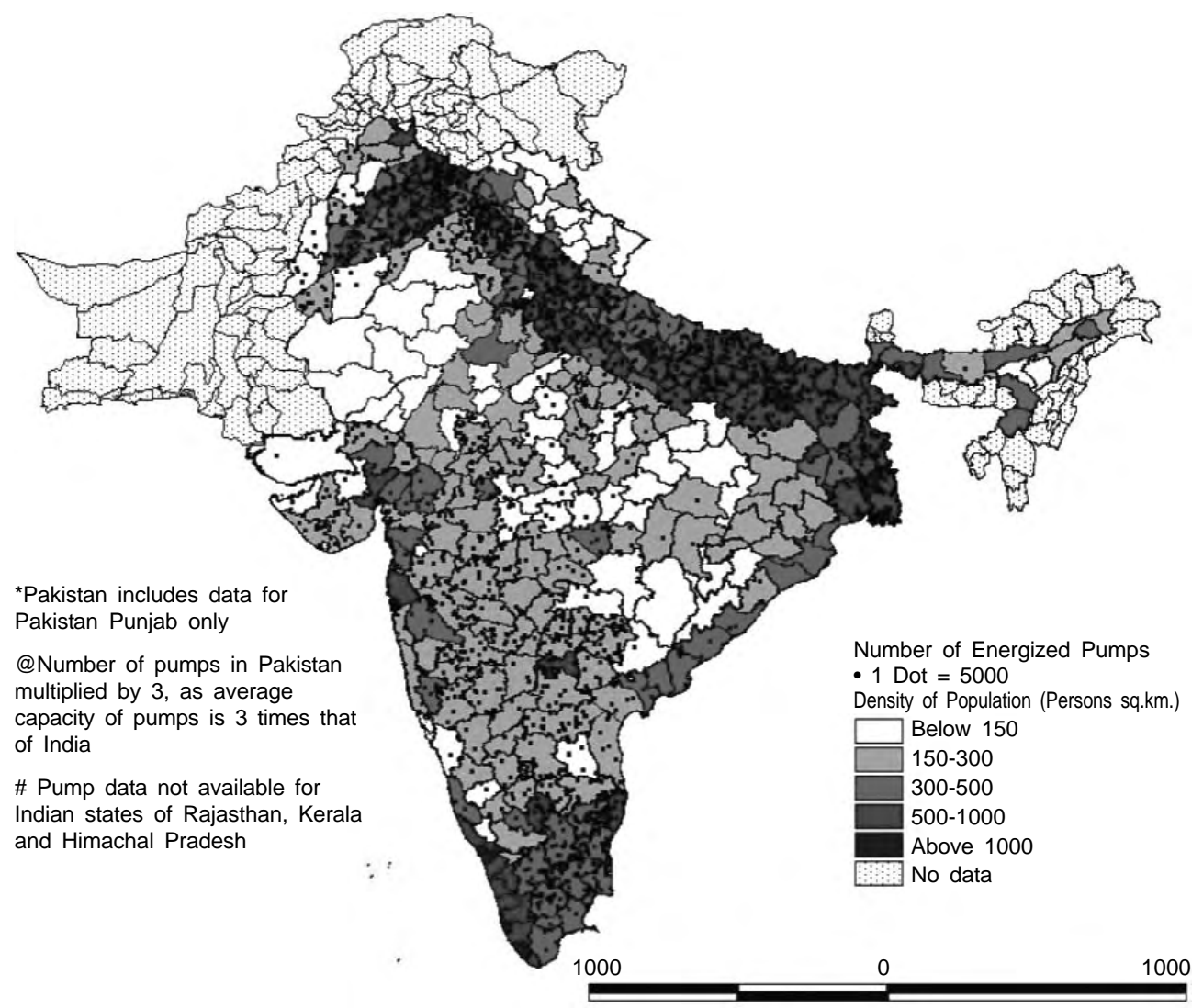

Figure 3. Density of population and distribution of energized pumps in India and Pakistan 


\section{Groundwater Governance: Institutions, Laws and Policies}

This runaway growth in Type IV GwSE's in developing countries in Asia exemplifies best how poverty works as the enemy of environment. High population pressure on agriculture has induced farmers to overwork their tiny land holdings in search of more livelihoods per unit of all that land has to offer-soil nutrients, moisture and underlying groundwater. Widespread indications of groundwater depletion and deterioration, rising energy use and pumping costs, well failures, weakening drought-protection suggest that the 'groundwater boom', which has done more to sustain the poor than all poverty eradication programs, will burst, sooner or later. There are also environmental repercussions in the form of drying up of wetlands and streams, reduced lean season flows of rivers, and salinity ingress in coastal areas. Groundwater quality issues too have assumed serious proportions in many parts of the world; irrigating with saline groundwater, as in the Indus basin and in Australia, have raised the specter of soil salinization on large areas. People and policy makers in many parts of the world-but especially in South Asia and North China Plain- are waking up to the dangers of drinking poor quality groundwater high in arsenic or fluoride or other contaminants.

Effective management of groundwater demand to match available recharge is considered central to sustaining intensive groundwater use in Type IV GwSE's; and strategies recommended to them are those that have been tried out in Type II and III GwSE's. Community management of groundwater as a common property resource is widely espoused to South Asian policy makers based, for example, on the experience of countries like Spain and Mexico. The issue is if such models can or should be transplanted without ascertaining their effectiveness on their home turf. Spain's 1985 Water Law mandated Water User Associations at aquifer level; but of some 1400 that were registered, Martinez-Cortina and Hernandez-Mora (2003) could identify "only 2 which have actively managed their aquifers, financing all their activities from membership fees" (p.318). One reason why these failed, as Llamas points out, was that these users associations mandated top-down by law have been 'fraught with strong resistance from farmers' (Llamas 2003). Mexico likewise has been experimenting with COTAS (Technical Committee for Aquifer Management); these too are yet to begin playing effective role in aquifer management (Shah, Scott and Bucheler,2004). Groundwater districts of US are often held out as a model in community groundwater management; however, the US experience itself is a mixed bag. Since 1949, Texas allowed the creation of Underground Water Conservation Districts (UWCDs) with discretionary power to regulate groundwater withdrawals and space wells as well as their production. However, Smith (2003:264265) notes, "Although over forty UWCDs have been created in Texas, they have not been effective managers of groundwater." and further that "..creating groundwater districts is not-in and of itself-going to ensure sound groundwater management."

Demand restriction has also been tried through a combination of pricing, legislative and regulatory action, licensing and permits, and by specifying property rights. Direct regulation worked better in countries with a hard state, as in Iran, which imposed an effective ban on new tubewells in 1/3rd of its central plains, or Russia which has banned the use of groundwater for irrigation to protect it for domestic uses (Igor.S Zektser, pers. Comm.). However, bans proved counter- 
productive in Mexico, which has issued 14 bans on new tubewells since 1948; however, "every announcement of an imminent ban stimulated a flurry of tubewell making activity" (Shah, Scott and Buecheler, 2004). Mexico has also tried, in early 1990's, creating tradable private property rights in groundwater by issuing 'concessions' to tubewell owners with pre-specified volumes of groundwater to be pumped every year. The idea was that once private water rights are created, users would have strong incentive in protecting the resource, especially if such rights were valuable and tradable (Holden and Tobani 2001). Concessions have led to registration of tubewells, useful in itself; but enforcing the groundwater quota has proved administratively impossible even though Mexico has all of 90,000 irrigation tubewells, compared to North China's 4.5 million and India's 20 million. China's water withdrawal permits system and withdrawal fees have not helped reduce agricultural withdrawal although it has helped control urban groundwater depletion somewhat. Saudi Arabia has begun controlling groundwater irrigation by paying farmers for supplying water to towns (Abderrahman, 2004. Pers. Comm.).

In transposing the lessons from Mexico, Spain, western US experiments to Asian contexts, several issues come up: (a) there is no evidence that these experiments have actually led to effective resource governance in Mexico, Spain or the US; western US has been struggling with groundwater governance for over 50 years now; and yet horror stories of groundwater abuse in the US galore (for a recent one, see, Glennon's book "Water Follies" reviewed by Jehl 2002); (b) groundwater demand restriction has normally worked only when alternative supplies are arranged; thus many cities in North China have been able to crowd out private urban tubewells but only after importing surface water and providing it in lieu of pumping groundwater. Similarly, 50 years after it began depleting its groundwater, Arizona could control groundwater demand only by providing farmers subsidized Colorado River water in lieu of pumping groundwater. (Jacobs and Holway, 2004:58). Spain's 2001 National Water Plan's response to groundwater depletion on its southeastern Mediterranean coast is importing surface water from Ebro river basin (Martinez Cortina and Hernandez-Mora, 2003). In effect, then, what has commonly worked is not demand management, but 'groundwater substitution' with imported water; (c) finally, the socio-economic context of Type III and Type IV GwSE's are so vastly different, that copycat transfer of lessons from former to later would be bound to fail as can be inferred from Table 1. The US has small number of large capacity pumping plants that produce $110 \mathrm{~km}^{3}$ of groundwater for

Table 1. Structure of national groundwater economies of selected countries

\begin{tabular}{lcccc}
\hline Country & $\begin{array}{c}\text { Annual ground } \\
\text {-water use } \\
\left(\mathrm{km}^{3}\right)\end{array}$ & $\begin{array}{c}\text { No of ground- } \\
\text { water structures } \\
\text { (million) }\end{array}$ & $\begin{array}{c}\text { Extraction/ } \\
\text { structure } \\
\left(\mathrm{m}^{3} / \text { year }\right)\end{array}$ & $\begin{array}{c}\% \text { of population } \\
\text { dependent on } \\
\text { groundwater }\end{array}$ \\
\hline India & $185-200$ & 20.0 & $9000-10000$ & $55-60$ \\
Pakistan & 45 & 0.5 & 90000 & $60-65$ \\
China & 75 & 3.5 & 21500 & $22-25$ \\
Iran & 29 & 0.5 & 58000 & $12-18$ \\
Mexico & 29 & 0.07 & 414285 & $5-6$ \\
USA & 110 & 0.2 & 550,000 & $<1-2$ \\
\hline
\end{tabular}


a wealth-generating irrigation machine on which less than $2 \%$ of Americans depend for their livelihood. India, in contrast, has around 20 million small pumps scattered over a vast countryside, each pumping on average $10,000 \mathrm{~m}^{3}$ to irrigate their tiny parcels in a peasant economy that has 55-60 percent of Indians as direct or indirect stake holders. Here, resource management capacities are poor. Regulatory agencies are skeletal and the numbers of tiny users to be regulated huge and scattered over a vast countryside. Then, because groundwater irrigation is central to their livelihoods, farmers organize readily-and often violently-to oppose any effort that hits their irrigation economy. Above all, many environmental ill effects of intensive groundwater use begin to occur at low levels of groundwater development. Drying up of wetlands, reduction in summer low flows in rivers and streams, increased fluoride levels in groundwater are examples. Reversing all these would require restoring pre-development conditions by cutting the present rate of groundwater use by 70 percent or more in many regions. Even if possible, doing this would throw out of gear millions of rural livelihoods and cause massive social unrest.

\section{Context Specific Strategies: The Case of India}

This is why people, agencies and leaders in Type IV GwSE's are often lukewarm to 'groundwater demand restriction' approaches even as concerns about resource protection and sustainability are mounting. While learning intelligently from the experiences of Type II and III GwSEs, Type IV socio-ecologies need to build their homegrown approaches that strike a balance between the need to protect the resource and support their poor people. India exemplifies this challenge in its most serious form. It is facing unsustainable groundwater use in western unconfined alluvial aquifers, very much like the North China plains, as well as in peninsular hard-rock India where aquifers have little storage but precipitation is relatively better. Three large-scale responses to groundwater depletion in India have emerged in recent years in an uncoordinated manner, and each presents an element of what might be its coherent strategy of resource governance:

(i) Energy-irrigation nexus: Throughout South Asia, the 'groundwater boom' was fired during the 1970's and 80's by government support to tubewells and subsidies to electricity supplied by state-owned electricity utilities to farmers. The invidious energy-irrigation nexus that emerged as a result and wrecked the electricity utilities and encouraged waste of groundwater are widely criticized. However, hidden in this nexus is a unique opportunity for groundwater managers to influence the working of the colossal anarchy that is India's groundwater socioecology. Even while subsidizing electricity, many state governments have begun restricting power supply to agriculture to cut their losses. Much IWMI research has shown that with intelligent management of power supply to agriculture, energyirrigation nexus can be a powerful tool for groundwater demand management in Type IV socio-ecologies (Shah et al, 2003b). IWMI research has also shown that after all its labors to create tradable property rights in groundwater and creating COTAS, Mexico has finally had to turn to electricity supply management to enforce its groundwater concessions (Scott, Shah and Buechler 2003). 
(ii) Inter-basin transfers to recharge unconfined alluvial aquifers: In western India's unconfined alluvial aquifers, it is being increasingly realized that groundwater depletion can be countered only by importing surface water, Arizona-style. Jiangsu province in eastern China has implemented its own little inter-basin water transfer from Yangzee to counter groundwater depletion in the northern part. Similarly, one of the major uses Gujarat has found for the water of the by now famous Sardar Sarovar Project (SSP) on Narmada river is to recharge the depleted aquifers of north Gujarat, and Kachchh. A key consideration behind India's proposed megascheme to link its northern rivers with peninsular rivers too is to counter groundwater depletion in western and southern India.

(iii) Mass-based recharge movement: In many parts of hard-rock India, groundwater depletion has invoked wildfire community-based mass movement for rainwater harvesting and recharge, which interestingly has failed to take off in unconfined alluvial aquifers. It is difficult to assess the social value of this movement partly because 'formal hydrology' and 'popular hydrology' have failed to find a meeting ground. Scientists want check dams sited near recharge zones; villagers want them close to their wells. Scientists recommend recharge tubewells to counter the silt layer impeding recharge; farmers just direct floodwaters into their wells after filtering. Scientists worry about upstream-downstream externalities; farmers say everyone lives downstream. Scientists say the hard-rock aquifers have too little storage to justify the prolific growth in recharge structures; people say a recharge structure is worthwhile if their wells provide even $1000 \mathrm{~m}^{3}$ of life-saving irrigation/ ha in times of delayed rain. Hydrologists keep writing the obituary of the recharge movement; but the movement has spread from eastern Rajasthan to Gujarat, thence to Madhya Pradesh and Andhra Pradesh. Protagonists think-as caricatured in Figure 4- that with better planning of recharge structures and larger coverage, decentralized recharge movement can be a major response to India's groundwater depletion because it can ensure that water tables in pockets of intensive use rebound close to pre-development levels at the end of the monsoon season every year they have a good monsoon, which is at least twice in 5 years. They surmise that this is not impossible because even today, India's total groundwater extraction is barely $5 \%$ of its annual precipitation.

An important aside to India's groundwater story is that it has emerged as a truly people's GwSE. Indian governments at centre and state levels have been trying for decades to secure people's participation in improving the management of canal systems, water supply and sanitation systems, drainage systems and so on, but to little avail. As a result, under remote, bureaucratic management, public water infrastructure and services have steadily deteriorated. The groundwater economy, in contrast, has never suffered for want of people's participation. What it has lacked is appropriate and intelligent participation from public agencies, science institutions and the international community. Indian engineers take pride in having built some of the finest dams in the world; but India is yet to see largescale initiatives in ASR (Aquifer Storage and Recovery) as in New South Wales, or learn to operate major groundwater banking operations as in Arizona, or master the art of depleting and refilling aquifers on an annual basis as the French do with the Montpiller aquifer

Considered from this perspective, one can stand India's groundwater problem 
on its head; and argue that the emergence of intensive groundwater use in regions with 1000-1400 mm normal rainfall may well be a great hidden opportunity. Through their 20 million tube wells, India's farmers have created a $185-200 \mathrm{~km}^{3}$ reservoir-in the form of dewatered aquifers-which can regularly collect, store and deliver at the users' door-step a relatively high quality water service that in some ways is 'self-regulating and self-financing'. Like all surface reservoirs, the underground reservoir has limitations; but this is precisely why science and management are required. Using this opportunity would require investing in creating scientific capability and infrastructure for groundwater recharge a top priority for Type IV GwSE's such as India and Bangladesh with significant renewable water resources. Hundred years ago, when India did not use much groundwater and the tubewell-pump-recharge technologies were not available, it was understandable for the colonial government to concentrate resources on building great canal irrigation systems. But today-when wells, pumps and recharge structures are the dominant choice of millions of India's small holders, within and outside canal commands-a smart water policy might focus on devoting resources to supporting this people's GwSE rather than throwing good money after bad, as

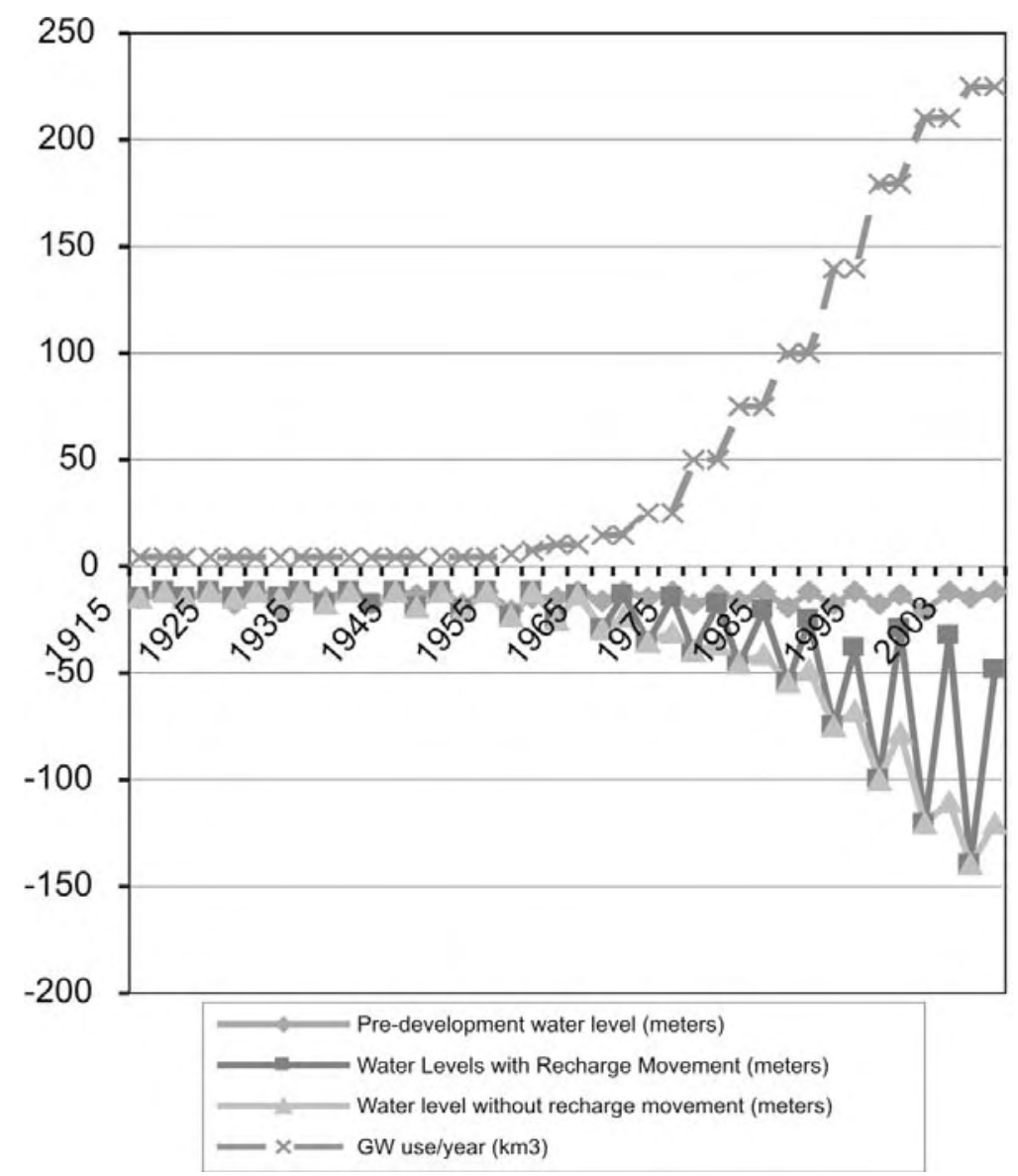

Figure 4. Farmers' perception of potential impact of decentralized recharge movement in India 
India is intent on doing, in pursuing an irrigation development strategy based on canal irrigation that has left a great deal to be desired.

\section{Summary and Conclusion}

If the world's water crisis is "mainly a crisis of governance" (GWP, 2000), groundwater represents the grimmest side of this crisis in Asia. The Australian Groundwater School at Adelaide is apt in its credo, which says, "Groundwater will be the enduring gauge of this generation's intelligence in water and land management". In exploring the nature of the global groundwater challenge, this paper has (a) highlighted the tremendous contribution groundwater has made to human welfare globally; (b) analyzed socio-ecological implications of runaway growth of groundwater irrigation, especially in some Asian countries; and (c) argued why groundwater governance strategies must be context-specific to be effective.

Type IV GwSE's-where protecting the resource is often in direct and immediate conflict with livelihood support to rural poor-presents the most complex resource governance challenge facing the world's water professionals. Groundwater managers in Type IV GwSE's need to learn intelligently from approaches tried in Type II and III GwSE's, which have been evolving, refined structures of groundwater governance through demand and supply side management. Their challenge, however, is to fit these approaches into the unique contextual realities of Type IV GwSE's.

\section{References}

BBS (Bangladesh Bureau of Statistics). 2002. Statistical Yearbook of Bangladesh. Statistics Division, Ministry of Planning, Govt. of the People's Republic of Bangladesh, Dhaka.

Burke, J. 2003. "Groundwater for irrigation: productivity gains and the need to manage hydroenvironmental risk", in R Llamas and Custodio, E [eds.] Groundwater Intensive Use: Challenges and Opportunities, Lisse, The Netherlands: Swets and Zeitlinger, B.V.

Coughanowr, C. 1994. Ground water, Paris: UNESCO, IHP Humid Tropics Program series No 8.

DebRoy, A., and Shah, T. 2003. 'Socio-ecology of Groundwater Irrigation in India', in Llamas, R \& E. Custodio (eds.) Intensive Use of Groundwater: Challenges and Opportunities, cited above.

Global Water Partnership. 2000. Towards Water Security: A Framework for Action. GWP. March 2000.

Government of India. 2001. Report on Census of Minor Irrigation Schemes - 1993-94, Ministry of Water Resources, Minor Irrigation Division, Government of India.

Holden, P. and Tobani, M. 2001. Tradable water rights: a property rights approach to resolving water shortages and promoting investment, Washington: The World Bank, Policy Research Working Paper, WPS 1627.

Jacobs, K. and Holway, J. 2004. "Managing for sustainability in an arid climate: Lessons learned from 20 years of groundwater management in Arizona, USA", Hydrogeology Journal (2004), 12: 5264.

Jehl, D. 2002. “Out of Sight, Out of Mind: An oncoming crisis over misuse of a hidden resourceAmerica's aquifers", Scientific American, December 16. which is a review of Glennon's "Water Follies".

Llamas, R. 2003. “Epilogue", Water International, 28(3): 405-409.

Martinez Cortina, L. and Hernandez-Mora, N. 2003. “The role of Groundwater in Spain's Water Policy, Water International, 28(3): 313-320.

Molle, F., Shah, T. and Barker, R. 2003. The groundswell of pumps: Multilevel impacts of a silent revolution. Paper presented in ICID-Asia Meeting, Taiwan, November 2003. 
Puri, S. and Nasser, H.El. 2003. "Intensive Use of Groundwater in Transboundary Aquifers", in R Llamas and Custodio, E [eds.] Groundwater Intensive Use: Challenges and Opportunities, cited earlier.

Scott, C.A., Shah, T. and Buechler, S.J. 2003. Energy pricing and supply for groundwater demand management: Lessons from Mexican agriculture. Anand, India: IWMI-TATA Water Policy Research Highlight No.3.

Shah, T., DebRoy, A., Qureshi, A.S. and Wang, J. 2003(a). "Sustaining Asia's Groundwater Boom: An Overview of issues and Evidence". Natural Resources Forum, 27(2003): 130-140.

Shah, T., Scott, C. and Buechler, S. 2004. Water Sector Reforms in Mexico: Lessons for India's New Water Policy. Economic and Political Weekly, Vol. XXXIX, No. 4: 361-370.

Shah, T., Scott, C., Kishore, A. and Sharma, A. 2003(b). Energy-Irrigation Nexus in South Asia: Improving Groundwater Conservation and Power Sector Viability. Colombo, Sri Lanka: International Water Management Institute Research Report No.70.

Smith, Z.A. 2003. Groundwater collective management systems: the United States experience", in R Llamas and Custodio, E [eds.] Groundwater Intensive Use: Challenges and Opportunities, cited earlier. 